\title{
Leadership Roles for Mindful Schools: Examining Relationships Between Different Leadership Roles of School Principals and School Mindfulness
}

\author{
Gülay Öngel ${ }^{1}$, Erkan Tabancalı ${ }^{2} \&$ Mithat Korumaz $^{2}$ \\ ${ }^{1}$ Şehit Batuhan Ergin Anatolian High School, İstanbul, Turkey \\ ${ }^{2}$ Yildiz Technical University, İstanbul, Turkey \\ Correspondence: Gülay Öngel, Şehit Batuhan Ergin Anatolian High School, İstanbul, Turkey.
}

Received: September 1, 2021

Accepted: November 16, 2021

Online Published: January 17, 2022

doi:10.5539/ies.v15n1p63

URL: https://doi.org/10.5539/ies.v15n1p63

\begin{abstract}
The purpose of this study is to reveal leadership roles of school principals having impact on school mindfulness. This quantitative study with correlational design involves 389 teachers from secondary and high schools in Buyukcekmece, Istanbul province. The researchers used the 'School Mindfulness' and 'Leadership Roles of School Principals' scales. In the study descriptive statistics, correlation and regression analyses were used to reveal the prediction level. The findings showed that visionary and transformational leadership roles of school principals strengthen school mindfulness and the sub-categories of faculty and school principal mindfulness. In addition, instructional leadership roles of school principals predict principal mindfulness. However, cultural leadership was found to have no effect on school mindfulness.
\end{abstract}

Keywords: school mindfulness, principal mindfulness, transformational leadership, visionary leadership

\section{Introduction}

Mindfulness is defined as an individual and organizational approach in which principals and teachers are attentive, open to novelties, committed to dealing with crises, valuing expertise, willing to collaborate and being responsive to operations at school (Hoy, 2002; Hoy, Gage, \& Tarter, 2004; Weick \& Stucliffe, 2001). Mindfulness protects individuals from misunderstandings arising from interpreting the present through preoccupation with past experiences. Mindfulness includes being aware of what is occurring in the present moment, being open to experiences and perceiving the differences between contexts. It helps us to perceive what is happening around us more objectively. It contributes to seeing events as they are by getting rid of our past experiences (Langer \& Ngnoumen, 2017). Weick and Sutcliffe (2006) pointed out that mindfulness allows us to be careful in adapting the way we think, act and behave in accordance with the present moment. When individual and organizational mindfulness develop, positive employee behaviors increase (Valentine, Godkin, \& Varca, 2009), change happens easily (Aviles \& Dent, 2015; Rerup \& Levinthal, 2014), and negative thoughts and emotions (Long \& Christian, 2015) and hasty behaviors decrease (Long \& Christian, 2015; Glomb, Duffy, Bono, \&Yang, 2011; Roche, Haar, \& Luthans, 2014). In addition, mindfulness contributes to the development of the quality of organizational outcomes (Ndubisi, 2012; Shapiro, Wang, \& Peltason, 2015), improves individual control (Wolf, Vykoukal, \& Beck, 2009), and decreases organizational conflicts (Yu \& Zellmer-Bruhn, 2017). Moreover, mindfulness suggests evaluating events from different perspectives, thus offering a broader foresight for the future. Being aware of different possibilities arouses attention and interest in different solutions (Bailes, 2015).

Mindfulness adds to the creation of a reliable climate among teachers and school administrators (Hoy, Gage, \& Tarter, 2006; Tabancalı \& Öngel, 2020). The literature has many studies investigating the positive impact of principal mindfulness on individual behaviors and organizational elements in the work environment (Chughtai \& Buckley, 2009; Kearney, Kelsey, \& Herrington, 2013; Well, 2015). The mindfulness of the manager improves the psychology of the employees in a positive way. This affects workers' motivation. Employees feel that they are upheld more by their superiors, and their feeling of trust grows (Reb, Narayanan, \& Chaturvadi, 2014).

According to organizational terminology, leaders are the founders and continuators of organizations (Ott, 1994). Moreover, they influence other individuals to make them voluntarily contribute to the group (Kaiser, Hogan \& Craig, 2008). In this respect, principals can play a key role in transforming schools into conscious organizations 
because of their leadership roles (Kavanagh \& Ashkanasy, 2006). Hoy, Gage, and Tarter (2006) stated that school leadership was important in raising school mindfulness. However, just as there is not a single style of leadership, leaders utilize various leadership styles in order to motivate their followers (Amanchukwu, Stanley, \& Ololube, 2015). For this reason, it is important to identify leadership roles that will facilitate the development of mindful organizations, individuals and groups.

The literature has many studies examining the positive impact of mindfulness on the individual as well as the managerial and organizational elements in the work environment (Aviles \& Dent, 2015; Hanson, 2019; Long \& Christian, 2015; Ndubisi, 2012; Spanjian, 2019; Wolf, Vykoukal, \& Beck, 2009). However, the studies on how to develop and strengthen organizational mindfulness are quite limited. For this reason, this study aims to examine the leadership roles having an impact on school mindfulness, referred to as teacher mindfulness and principal mindfulness. School principals are able to develop positive organizational behaviors thanks to school mindfulness. Thus, the study is important in investigating the impact of leadership roles of principals as an element that strengthens school mindfulness on mindfulness and presenting data concerning leadership styles that will improve principal and school mindfulness.

\subsection{School Mindfulness}

Mindfulness is the state of conscious attentiveness referring to the control of attention. According to Langer (1992), mindfulness is the act of consciously processing the meaning and context of any situation, developing different points of view for every instance and creating new categories. Besides, it suggests paying attention to physical sensations of the present moment without prejudices (Collard, 2014). Prejudices may inhibit individuals in their ability to notice alternatives and innovations. Most of people keep on living while lacking natural cognizance in their everyday schedules (Smith \& Scarbrough, 2011). Individual mindfulness involves monitoring every second and assessing each occasion independently without judgment. Mindful people look for the characteristic features of the occasions and, particularly, strive to uncover essential causes and signals of potential issues (Hoy, Gage, \& Tarter, 2006). Schools are open institutions to the influence of many factors. However, many factors such as interdependence, complexity in the network and time pressure make it difficult to perceive the problems and the necessities of change (Youngs, 2018). To avoid these problems, education leaders should follow dynamic organizational approaches that create and develop quality learning environments (Fatema, 2019).

Mindfulness, regarded as a dynamic organizational approach by Weick and Stucliffe (2001), was adapted to organizational operations through five different processes. Hoy, Gage, and Tarter (2004) organized these five processes in a way that formed a conceptual framework for schools with an aim to conceptualize school mindfulness and make it more functional.

Sensitivity to operations: Practices that have become routine as a result of countless repetitions create certain behavioral patterns over time. It becomes increasingly difficult to break out of these behavioral patterns. Ultimately, people cannot decide what to do in situations that require new forms of behavior (Langer \& Moldoveanu, 2000; Scarbrough, 2005; Weick \& Sutcliffe, 2006; Weick, 2009; Weick \& Sutcliffe, 2015). Being sensitive to operations allows you to break out of routine and be sensitive to every practice in a school. Approaching every event with precision enables you to produce appropriate solutions to problems. Sensitivity to operations means teachers and principals being in close interaction with one another and being closely tied to all the operations that the school conducts (Bauch, 2014; Ginn, 2014).

Preoccupation with failure: Being mindful makes it easier to face problems. The focus is on the mistake, not the ones who make mistakes, and collective solutions are sought (Mu \& Butler, 2009; Ndubisi \& Al Shuridah, 2019; Weick \& Sutcliffe, 2007). Mindfulness helps individuals to constantly scan for problems in the school environment. In this way, individuals identify the antecedents of possible problems more easily (Hoy, Gage, \& Tarter, 2004). And because individuals know they will not be blamed for problems, they can express problems easily instead of covering them up. Thus, it becomes easier to solve and overcome problems.

Reluctance to simplify: Schools are complex organizations in which a number of individuals proceed by separate actions; on the other hand, these individuals need to work in cooperation on some issues. For this reason, the organization leader and members try to find ways to understand complex events and solve problems with a realistic approach as much as possible (Hoy, 2002). Without simplifying the events, and by evaluating all the details, appropriate solutions are reached (Bauch, 2014). Taking problems seriously rather than ignoring them helps us seize opportunities for change and stay in control (Mu \& Butler, 2009).

Commitment to resilience: Mindfulness does not only allow schools to prevent possible mistakes, it also allows them to deal with these mistakes (Scarbrough, 2005). Being determined to deal with any crises refers to the determination to resolve the problems identified by principals and teachers. Mindless organizations look for the 
person who made the mistake while mindful organizations look for solutions. The source of the problem is investigated and new learning is performed in order not to make the mistakes again (Bauch, 2014). Mindful organizations have the ability to deal with problems quickly and recover after crises (Weick \& Sutcliffe, 2006; Weick, 2009; Williamson, 2010; Weick \& Sutcliffe, 2015).

Deference to expertise: Mindful organizations avoid the mistake of valuing individuals' hierarchical positions, ranks, or superior-subordinate relations. Instead, the expertise required to solve the problem is the first priority in such organizations. The individuals taking part in the resolution process are determined based on their expertise. The decision-making process is, therefore, quite fluid and the opinions of those who have expertise related to the problem are valued (Hoy, Gage \& Tarter, 2006; Ndubisi \& Al Shuridah, 2019). Commitment to expertise requires the use of knowledge -that is, expertise- independently of hierarchy in case of a problem. In mindful schools, problems are solved with expertise instead of power (Bauch, 2014).

\subsection{The Leadership Roles of School Principals and School Mindfulness}

Leaders have such features as influencing and directing the behavior of others, creating new strategies, communicating effectively and having different perspectives. These characteristics of the leader can contribute to developing individual and organizational mindfulness (Horowitz, 2012). Specific leadership behaviors appropriate to the nature of mindfulness can play a more effective role in the development of individual and organizational mindfulness. For example, according to Vogus and Sutcliffe (2012), transformational leadership may create organizational mindfulness and facilitate mindful organizing. Firstly, transformational leadership aims to contribute to teacher development, to enhance the capacity to resolve the problems effectively as an individual and organization and to promote cooperation (Leithwood, 1992) as well as to build both individual and organizational capacity to improve learning and teaching activities, which are the main focus of schools (Hallinger, 2003). Transformational leadership, in other words, refers to a leader-follower interaction that encourages subordinates to act beyond their potential (Northouse, 2014). In this regard, there are certain similarities between organizational and individual mindfulness practices in that they require such behaviors as sensitivity to operations, determination to deal with problems, collaboration and collaboration, which are the objectives of transformational leadership. Therefore, it may be concluded that transformational leadership correlates with mindfulness (Walsh \& Arnold, 2017). Again, the study conducted by Gieseke (2014) indicated a relationship between mindfulness and transformational leadership.

Second, visionary leadership is assumed to have an impact on the development of organizational mindfulness. A visionary leader can appreciate the feelings and needs of his/her subordinates, empower the individuals in the workplace, improve group performance, create clear visions providing determination and make subordinates adopt this vision (Stoner-Zemel, 1988). Effective leaders develop visions which achieve positive outcomes in terms of their followers, and these visions help subordinates gain self- competence (Northouse, 2014). As leader behavior, developing vision facilitates the integration of the organization's strategical goal and mindfulness. The leader's ability to appreciate the feelings of his/her followers is associated with his/her mindfulness. Understanding the emotional climate and functioning of an organization is the starting point for a leader. Thus, creating an effective and realistic vision may improve both the principal's and organization's goals in addition to raising mindfulness towards suitable functioning that is consistent with these goals (Walsh \& Arnold, 2017).

School mindfulness requires principals and teachers to be sensitive towards the educational operations, which are the main foci of the schools. Instructional leadership is the role of leadership that is consistent with the general perspectives of school principals towards the schools (Dwyer, Bbarnett, \& Lee, 1987). In this context, the role of instructional leadership may enhance school mindfulness. The term instructional leadership is defined as an approach related to teachers' professional self-development, adaptation of school's physical characteristics to education, and transformation of other stakeholders (King, 2002). Besides, instructional leaders aim to enhance continuing development to provide effective teaching and to improve collective effort concerning learning and teaching (Blase \& Blase, 1999). Instructional leadership, also, may be beneficial in that principals and teachers deliberately carry out teaching and learning activities. Investigation of the relationship between mindfulness and instructional leadership may contribute to the enhancement of the mindfulness approach (Rodriquez, 2015).

As for cultural leadership, the leaders adopting this leadership style have the characteristics of understanding the nature of the organization, having shared opinions with subordinates and exploring rational ways to influence others through analyzing the cultural codes of the organization (Trice \& Beyer, 1991). Cultural leaders, as related to schools, identify and assess the cultural dynamics of the school since each organization has a unique culture. School cultures may function as a supplementary approach in terms of creating practices and insights to improve schools and developing common sense (Alton, 1994). Cultural leaders are able to find practical ways of achieving 
their goals (Sergiovanni, 1987). Furthermore, cultural leaders exhibit compatible behaviors with the culture they are in and regard this culture as an agent or catalyzer in order to improve individuals' potential. Besides, they are the facilitators of cultural interaction to enhance others' potential (Sutherland \& Gosling, 2010). Therefore, cultural leadership roles of the school principal may function as a facilitator in the development of mindfulness culture.

\section{Method}

This study is designed according to the quantitative approach and correlational research design. Correlational research design aims to ascertain the potency of a relationship in relation to two or more variables (Bridgmon \& Martin, 2012). The purpose of correlational design is to determine whether and to what degree a relationship exists between two or more variables or to use these relations to make predictions (Gay, Mills, \& Airasian, 2009; McMillan \& Schumacher, 2006). The purpose of this study is to reveal to what extent leadership roles of school principals have an impact on school mindfulness. In accordance with the aim of the research, the current study adopted the quantitative approach with relational research design, which allows the researcher to elucidate the relationship with two or more variables (Bridgmon \& Martin, 2012).

\subsection{Sample of the Study}

The research population consisted of 1560 secondary and high school teachers in the Büyükçekmece, İstanbul province in the 2020-2021 academic year. To determine the study group, the random sampling method was used. In random sampling, each element of the study group has an equal and independent chance of being selected (Özen \& Gül, 2007). To achieve 0.5 significance and a $95 \%$ confidence interval, 389 out of 1560 teachers selected in accordance with random sampling were included in the study (Yamane, 2009). Demographics of the participants are presented on Table 1.

Table 1. Participants of study

\begin{tabular}{ccc}
\hline Gender & $f$ & $\%$ \\
\hline Female & 183 & 47 \\
Male & 206 & 53 \\
Total & 389 & 100 \\
\hline Type of School & $\mathrm{f}$ & $\%$ \\
\hline Secondary School & 121 & 32.1 \\
High School & 268 & 68.9 \\
Total & 389 & 100 \\
\hline
\end{tabular}

Of all the participants $47 \%(n=183)$ were female, and $53 \%(n=206)$ were male. Besides, $32.1 \%(n=121)$ of the participants work in secondary schools and $68.9 \%(\mathrm{n}=268)$ o them work in high schools.

\subsection{Data Collection Procedure}

Data were collected with two scales. The first scale was the School Mindfulness Scale developed by Hoy, Gage and Tarter (2004) and adapted into Turkish by Tekel and Karadağ in 2019. The other scale was the Leadership Roles Scale developed by Tahaoğlu and Gedikoğlu in 2009. The reliability and validity analyses of the scales were conducted and the Cronbach-alpha coefficient of the school mindfulness scale was $0.944 ; 0.924$ for principal mindfulness; 0.890 for faculty mindfulness. In addition, the Cronbach-alpha coefficient of the second scale was 0.994; 0.977 for visionary leadership; 0.981 for instructional leadership; 0.982 for cultural leadership and 0.988 for transformational leadership.

\subsection{Data Analysis}

The data obtained in the study were analyzed using a statistical program for social science. Percentages, averages and standard deviations of the scales were tested with descriptive statistics. 
Table 2. Kurtosis and skewness values

\begin{tabular}{lcc}
\hline Sub-scales & Kurtosis & Skewness \\
\hline School Mindfulness & 0.111 & -0.875 \\
Principal Mindfulness & 0.563 & -1.126 \\
Faculty Mindfulness & 0.266 & -0.815 \\
Leadership & -0.067 & -0.989 \\
Instructional Leadership & -0.341 & -0.868 \\
Transformational Leadership & -0.197 & -0.978 \\
Visionary Leadership & -0.095 & -0.826 \\
Cultural Leadership & 0.001 & -0.920 \\
\hline
\end{tabular}

Moreover, Kurtosis and Skewness values were examined to determine whether the study variables were normally distributed. Kurtosis and Skewness values between +1.5 and -1.5 (Tabachnick \& Fidell, 2013) or +2.0 and -2.0 (Mallery \& George, 2010) are considered normal distribution. As the sampling is adequate according to the law of large numbers and the central limit theorem $(\mathrm{N}=389)$, the analyses were continued with the assumption that the distribution was normal (Harwiki, 2013; İnal \& Günay, 1993; Johnson \& Wichern, 2002). The prediction level of the independent variable to dependent variable was determined with regression analysis.

\subsection{Findings}

The school mindfulness level in accordance with the thoughts of participants was determined with descriptive statistics. The results are presented in Table 3 .

Table 3. Descriptive statistics for school mindfulness

\begin{tabular}{lccccc}
\hline Sub-scales & $\mathrm{N}$ & $\bar{X}$ & $\mathrm{fd}$ & Min. & Max. \\
\hline School Mindfulness & 389 & 3.863 & 0.853 & 1.00 & 5.00 \\
Principal Mindfulness & 389 & 3.849 & 0.967 & 1.00 & 5.00 \\
Faculty Mindfulness & 389 & 3.878 & 0.835 & 1.00 & 5.00 \\
\hline
\end{tabular}

The minimum score obtained from the School Mindfulness Scale was 1 point and the maximum was 5 points. Higher points on the scale represent a higher level of mindfulness. The mean of the School Mindfulness Scale is 3.863, meaning a high level of mindfulness. 'Principal mindfulness' was found to be high (3.849 \pm 0.967$)$, and 'faculty mindfulness' was also found to be high $(3.878 \pm 0.835)$.

Table 4. Descriptive statistics for leadership roles

\begin{tabular}{lccccc}
\hline Sub-scales & $\mathrm{N}$ & $\bar{X}$ & Fd. & Min. & Max. \\
\hline Leadership & 389 & 3.945 & 0.987 & 1.12 & 5.00 \\
Instructional Leadership & 389 & 3.959 & 0.996 & 1.21 & 5.00 \\
Transformational Leadership & 389 & 3.979 & 1.126 & 1.00 & 5.00 \\
Visionary Leadership & 389 & 3.878 & 0.882 & 1.24 & 5.00 \\
Cultural Leadership & 389 & 3.908 & 1.051 & 1.00 & 5.00 \\
\hline
\end{tabular}

The minimum score obtained from the Leadership Roles Scale was 1 point and the maximum was 5 points. Higher points indicate a higher level of leadership perception. The mean score of Leadership was 3.945, meaning a high level of leadership. 'Instructional leadership' was found to be high (3.959 \pm 0.996$)$, 'transformational leadership' to be high (3.379 \pm 1.126$)$, 'visionary leadership' to be high (3.878 \pm 0.882$)$, and 'cultural leadership' to be high (3.908 \pm 1.051$)$. 
Table 5. Results of correlation analysis

\begin{tabular}{llllllll}
\hline Variables & 1. & 2. & 3. & 4. & 5. & 6. & 7. \\
\hline $1 . \mathrm{SM}$ & 1.000 & & & & & & \\
2.PM & $.954^{* *}$ & 1.000 & & & & & \\
3.FM & $.938^{* *}$ & $.792^{* *}$ & 1.000 & & & & \\
4.IL & $.868^{* *}$ & $.874^{* *}$ & $.762^{* *}$ & 1.000 & & & \\
$5 . \mathrm{TL}$ & $.875^{* *}$ & $.878^{* *}$ & $.771^{* *}$ & $.944^{* *}$ & 1.000 & & \\
6.VL & $.929^{* *}$ & $.907^{* *}$ & $.848^{* *}$ & $.879^{* *}$ & $.872^{* *}$ & 1.000 & \\
7.CL & $.839^{* *}$ & $.844^{* *}$ & $.737^{* *}$ & $.919^{* *}$ & $.930^{* *}$ & $.854^{* *}$ & 1.000 \\
\hline
\end{tabular}

Note. SM-School Mindfulness, PM-Principal Mindfulness, FM-Faculty Mindfulness, VM-Visionary Leadership, IL-Instructional Leadership, CL-Cultural Leadership, TL-Transformational Leadership.

Instructional leadership and school mindfulness has significant and positive correlation $(r=0.868 ; p=0.000<0.05)$. In addition, there was a significant and positive correlation between instructional leadership and principal mindfulness $(\mathrm{r}=0.874 ; \mathrm{p}=0.000<0.05)$. Besides, a significant and positive relationship existed between instructional leadership and faculty mindfulness $(r=0.762 ; \mathrm{p}=0.000<0.05)$. Another finding of the study shows that transformational leadership was significantly and positively correlated with school mindfulness $(\mathrm{r}=0.875$; $\mathrm{p}=0.000<0.05)$. There was a significant and positive correlation between instructional leadership and principal mindfulness $(\mathrm{r}=0.878 ; \mathrm{p}=0.000<0.05)$. Finally, a significant and positive relationship was found between instructional leadership and faculty mindfulness $(\mathrm{r}=0.771 ; \mathrm{p}=0.000<0.05)$. Visionary leadership and school mindfulness were significantly and positively correlated $(r=0.929 ; \mathrm{p}=0.000<0.05)$. There was also a significant and positive correlation between visionary leadership and principal mindfulness $(r=0.907 ; p=0.000<0.05)$. A medium-level and positive relationship existed between visionary leadership and faculty mindfulness $(\mathrm{r}=0.848$; $\mathrm{p}=0.000<0.05)$. Cultural leadership was significantly and positively correlated with school mindfulness $(\mathrm{r}=0.839$; $\mathrm{p}=0.000<0.05$ ). Furthermore, there was a significant and positive relationship between visionary leadership and principal mindfulness $(\mathrm{r}=0.844 ; \mathrm{p}=0.000<0.05)$. A significant and positive relationship existed between cultural leadership and faculty mindfulness $(\mathrm{r}=0.737 ; \mathrm{p}=0.000<0.05)$.

Table 6. Results of regression analysis

\begin{tabular}{|c|c|c|c|c|c|c|c|}
\hline & Independent Variables & B & $\mathrm{t}$ & $\mathrm{p}$ & $\mathrm{F}$ & Model & $\mathrm{R}^{2}$ \\
\hline \multirow{4}{*}{ 1.SM } & IL & 0.049 & 0.961 & 0.337 & \multirow{4}{*}{712.547} & \multirow{4}{*}{0.000} & \multirow{4}{*}{0.881} \\
\hline & $\mathrm{Tl}$ & 0.200 & 4.275 & 0.000 & & & \\
\hline & $\mathrm{VL}$ & 0.667 & 17.844 & 0.000 & & & \\
\hline & $\mathrm{CL}$ & -0.039 & -0.924 & 0.357 & & & \\
\hline \multirow{4}{*}{ 2.PM } & IL & 0.129 & 2.042 & 0.042 & \multirow{4}{*}{571.869} & \multirow{4}{*}{0.000} & \multirow{4}{*}{0.856} \\
\hline & $\mathrm{TL}$ & 0.237 & 4.066 & 0.000 & & & \\
\hline & $\mathrm{VL}$ & 0.618 & 13.253 & 0.000 & & & \\
\hline & $\mathrm{CL}$ & -0.015 & -0.283 & 0.777 & & & \\
\hline \multirow{4}{*}{ 3.FM } & IL & -0.032 & -0.419 & 0.676 & \multirow{4}{*}{251.754} & \multirow{4}{*}{0.000} & \multirow{4}{*}{0.724} \\
\hline & $\mathrm{TL}$ & 0.163 & 2.330 & 0.020 & & & \\
\hline & VL & 0.716 & 12.835 & 0.000 & & & \\
\hline & $\mathrm{CL}$ & -0.062 & -1.001 & 0.317 & & & \\
\hline
\end{tabular}

Note. SM-School Mindfulness, PM-Principal Mindfulness, FM-Faculty Mindfulness, VM-Visionary Leadership, IL-Instructional Leadership, CL-Cultural Leadership, TL-Transformational Leadership.

The regression analysis conducted to determine the relationship between leadership roles (instructional, transformational, visionary and cultural) and school mindfulness was found to be statistically significant $(\mathrm{F}=712.547 ; \mathrm{p}=0.000<0.05)$. The prediction of the variables regarding the school principal's leadership roles on school mindfulness was strong $\left(\mathrm{R}^{2}=0.881\right)$. The transformational leadership role of the school principal increases school mindfulness $(\beta=0.200)$. Similarly, the visionary leadership role of the school principal increases school mindfulness $(\beta=0.667)$. However, the instructional $(\beta=0.049)$ and cultural $(\beta=-0.039)$ leadership roles of the school principal do not have an effect on school mindfulness.

The regression analysis conducted to determine the relationship between leadership roles (instructional, 
transformational, visionary and cultural) and principal mindfulness was found to be statistically significant $(\mathrm{F}=571.869 ; \mathrm{p}=0.000<0.05)$. The prediction of the variables regarding the school principal's leadership roles on principal mindfulness was strong $\left(\mathrm{R}^{2}=0.856\right)$. The instructional leadership role of the school principal increases principal mindfulness $(\beta=0.129)$. Besides, the transformational leadership role of the school principal increases principal mindfulness $(\beta=0.237)$. Moreover, the visionary leadership role of the school principal enhances principal mindfulness $(\beta=0.618)$. However, the cultural leadership role of the school principal does not have an effect on principal mindfulness $(\beta=-0.0315)$.

The regression analysis conducted to determine the relationship between leadership roles (instructional, transformational, visionary and cultural) and faculty mindfulness was found to be statistically significant $(\mathrm{F}=251.754 ; \mathrm{p}=0.000<0.05)$. The prediction of the variables regarding the school principal's leadership roles on faculty mindfulness was strong $\left(\mathrm{R}^{2}=0.724\right)$. The transformational role of the school principal increases faculty mindfulness $(\beta=0.263)$. The visionary leadership role of the school principal increases faculty mindfulness as well $(\beta=0.716)$. On the other hand, the instructional $(\beta=-0.032)$ and cultural $(\beta=-0.062)$ leadership roles of the school principal do not have an effect on faculty mindfulness.

\section{Results and Discussion}

This study aimed to examine the effects of leadership roles of school administrators on school mindfulness. Mindfulness is related to better control of attention, continuity of the attention towards goals, and effectivity. The previous studies on mindfulness posited that mindfulness enhanced performance, promoted performance in negative cases and encouraged behaviors concerning determined goals (Good et al., 2015). According to Hoy, Gage, and Tarter (2006), principals and teachers mostly carry out their duties based on rules and their previous experiences. When they consider the events, they see only the part of the situation they can manage. That is, they overlook those parts that they think they will not able to manage or deal with (Vogus \& Sutcliffe, 2001).

In fact, this is partly due to the restriction and suppression of creativity in organizations by rules and procedures (Weick \& Putnam, 2006). Likewise, school principals and teachers are impacted by numerous roles determined by others outside the school and by the goals to be achieved. It is very important for school administrators to propose goals and actions that will lead the school to new achievements and excellence under these besieged conditions (Ylimaki, 2006). It is important for school leaders to collaborate with teachers around a common purpose, understanding and vision and creating an indomitable organizational atmosphere in the face of problems. Thus, the collaboration which will help the organization achieve social and academic goals is built (Höög, Johansson, \& Olofsson, 2009).

Leaders should have the capacity to adopt a suitable leadership style in order to unearth human potential in the organization (Klockner \& Queensland, 2017). When mindfulness and leadership are implemented together, employees' attendance increases, the interaction between employee and leader improves, employees develop identification with their job, and their job satisfaction rises (Tarela \& Gbaraka, 2018). Mindful employees are less worried about their leaders' responses towards their opinions since the acceptance and rejection of an idea does not mean the rejection of the employee himself (Good et al., 2015). School leaders play a crucial role in creating an organizational structure to make the school successful (Mitchell, Mendiola, Schumacker, \& Lowery, 2016; Tschannen-Moran, 2010) and developing effective teacher behaviors (Anderson, Kochan, Kensler, \& Reames, 2018). Mindful schools are managed by school principals who are able to quickly deal with the problems faced and have the potential to make necessary changes (May, 2016). Besides, certain changes in leadership may have an impact on collective mindfulness, contributing to mindful interaction between employees (Kent, 2015; Roberts, Madsen, Desai, \& Stralen, 2005; Voulales \& Sharpe, 2004).

According to the findings of the study, the visionary leadership role of school principals enhances both school mindfulness and principal and faculty mindfulness, which are the sub-categories of school mindfulness. In cases in which organizational changes are necessary, the visions created by the leader play an important role in adapting organizations to new situations and providing the desired transformation in the organization (Archbald, 2013), and the visionary leader integrates the organization around these visions (Almong-Bareket, 2012). A strong vision raises mindfulness by empowering the perception about organizational existence (Barnett, Jermier, Lafferty, 2006). According to Knox, Simpson, and Garite (1999), a well-expressed purpose statement develops collective mindfulness. Creating a strong vision depends on a good analysis of the current situation. The analysis process requires the visionary leader to establish dialogue with all followers, scan documents, initiate new methods to access more data, and identify where the problems stem from. Apart from all these, in order to analyze the situation, it is important to see the system as a whole, to establish a cause-and-effect relationship between events, and to try to see beyond the events with the mindfulness that everything is changing (Satia, Kumar, \& Liow, 2014). 
The above-mentioned behaviors of visionary leaders may improve school mindfulness. Similarly, in mindful schools, school principals continuously determine disruptions within the school and try to find new information sources to overcome these challenges as well as frequently comunicate with teachers. By doing so, they are informed about events in the school and have the opportunity to notice disruptions in advance (Hoy, 2003; Hoy, Gage, \& Tarter, 2006).

The visionary leader's transforming novel ideas and ambitions promote certain behaviors to make necessary transformational change in order for the organization to achieve its goal (Milner \& Joyce, 2005). A visionary leader attempts to include the employees in the processes when organizational problems and opportunities are sought and to create new roadmaps in accordance with changing conditions instead of just using previous solutions (Schwahn \& Spady, 1998). New roadmaps for organizations to implement their daily operations are fundamental to organizational mindfulness. The fact that a specific behavior pattern produced a successful outcome in the past may cause such a behavior to become a habit. Principals and teachers prefer the behavior patterns which produced successful outcomes since they find it riskless. However, conditions, environments and problems mostly have unique characteristics and, therefore, entail novel solutions (Hoy, Gage, \& Tarter, 2004). The fundamental purpose underlying school mindfulness is to encourage individuals to give up non-functional behaviour patterns, to allow organizations to find new solutions and to enhance their effectiveness and achievement. The fact that visionary leaders probe into organizational opportunities and problems and attempt to create new roadmaps may contribute to improving principal and faculty mindfulness.

The results of the study indicate that transformational leadership enhanced school mindfulness and principal and faculty mindfulness, which are sub-categories of school mindfulness. Transformational leadership allows individuals to attentively consider their duties with a broader perspective (Vogues \& Sutcliffe, 2012) and contribute to developing workplaces which will improve employee performance (Bass \& Avolio, 1994; Piccolo \& Colquitt, 2006). It helps the organization go beyond its performance standards and raises employee mindfulness towards organizational goals (Yammarino, 1994). In addition, the creation of organizational mindfulness is a transformational process (Fraser, 2017). The right transformation can make the organization more effective. For this aim, such structural transformations as sharing power, renovating decision making mechanisms, and reconstructing methods and channels to receive information are required. The transformation processes commenced by transformational leaders encompass all the above-mentioned elements (Hacker \& Roberts, 2004; Marks \& Printy, 2003). Transformational leaders play a major role in transforming the organization into more functional structures, increasing the participation of employees and other stakeholders, transforming schools into mindful organizations and enhancing collaboration. The reason for this is the collaboration and participation among stakeholders in the school is important for school mindfulness.

The purpose of transformational leadership is to create a vigilant mind that is conscious of the opportunities in life as well as organizational goals (Hacker \& Roberts, 2004). Moreover, transformational leadership refers to the process of profound understanding of other stakeholders (Marshall, 2011). This approach facilitates transformational leadership's efforts to develop and improve their subordinates' self- efficacy (Pillai \& Williams, 2003). In addition, these leaders analyse both their subordinates' and own behaviors to empower employees (Jung \& Avolio, 2000; Marshall, 2011). In summary, the behaviors of transformational leaders can be considered in three dimensions; the intellectual stimulation dimension, which triggers professional development with the continuous revision of daily practices and professional knowledge, the vision building dimension, which makes organizational goals an effective element in organizational practices, and the dimension of individual consideration, which takes into account the feelings and needs of teachers (Geijsel, Sleegers, Stoel, \& Krüger, 2009; Geijsel, Van den Berg, \& Sleegers, 1999). For all these reasons, transformational leadership may contribute to employee potential and collective mindfulness oriented towards goals in order to bring about the sub-categories of organizational mindfulness. The fact that transformational leaders focus on organizational opportunities and goals may help the sensitivity to operations, which is the sub-category of organizational mindfulness, to develop. Similarly, increasing the employees' self-efficacy levels and evaluating the contributions made to the organization may allow the sub-category of deference to expertise to emerge.

The school principal as a leader plays a critical role in student achievement. With this aim, school principals are required to identify the most appropriate strategies for their schools and to implement these strategies in order to encourage effective teacher behaviors and student achievement (Anderson, Kochan, Kensler, \& Reames, 2018). Instructional leadership refers to the style of leadership which values student learning and helps teachers adopt novel teaching strategies (Smith, 2016). The findings of the present study indicate that instructional leadership roles of the school principal increased principal mindfulness. The fact that school principals develop strategies towards increasing student achievement within the school and collaborate with teachers for this aim may 
contribute to improve the sub-categories of sensitivity to operations and deference to expertise. Furthermore, the current study revealed that cultural leadership did not have an effect on principal, school and faculty mindfulness. The participants of the study did not consider the cultural leadership role (Toprakçı, 2002), which aims to ensure mutual interaction between the cultural environment and the leader, and to reveal the cultural developments created by this interaction, as an element that increases school mindfulness.

The current study provides insights into two fundamental phenomena, which are the leadership roles of school principals and school mindfulness, that are likely to improve schools' organizational operations. School principals exhibit behaviors oriented at empowering and supporting teachers (Sinden, Hoy, \& Sweetland, 2004). Likewise, organizational mindfulness represents the focus on weaknesses and malfunctions within the organization as well as being aware of the indicators of problems, improving collective learning and developing skills in the organization. Mindfulness, through numerous procedures and behaviours, helps the organization give reformatory responses instead of avoiding deteriorating conditions (Engemann \& Scott, 2018). The purpose of these phenomena is to improve the stakeholders' individual efficacy, development and participation, thus commencing and sustaining a change that will enable organizational improvement. Organizational mindfulness refers to an individual and collective mindfulness of the entire school towards all operations. In this regard, the fact that school principals utilize certain leadership roles as strategical transformation instruments to create and enhance school mindfulness is presumably beneficial in terms of individual and collective mindfulness.

\section{References}

Allton, J. (1994). Perspectives on the principal as a cultural leader. American Secondary Education, 23(1), 2-5.

Almong-Bareket, G. (2012). Visionary leadership in business schools: An institutional framework. Journal of Management Development, 31(4), 431-440. https://doi.org/10.9774/GLEAF.3709.2015.ju.00005

Amanchukwu, R., S. G., \& Ololube, N. (2015). A review of leadership theories, principles and styles and their relevance to educational management. Management, 5(1), 6-14. https://doi: 10.5923/j.mm.20150501.02.

Arendt, J., Verdorfer, A., \& Kugler, K. (2019). Mindfulness and leadership: Communication as a behavioral correlate of leader mindfulness and its effect on follower satisfaction. Front Psychol, 29, 660-667. https://doi.org/10.3389/fpsyg.2019.00667

Aviles, P. R., \& Dent, E. B. (2015). The role of mindfulness in leading organizational transformation: A systematic review. The Journal of Applied Management and Entrepreneurship, 20(3), 31-55. https://doi.org/10.9774/GLEAF.3709.2015.ju.00005

Bailes, L. (2015). Predictors of school effectiveness. In M. F. DiPaola, \& W. K. Hoy (Eds.), Leadership and school quality (pp. 147-161). Charlotte: Information Age Publishing.

Barnett, M., Jermier, J., \& Lafferty, B. (2006). Corporate reputation: The definitional landscape. Corporate Reputation Review, 9(1), 26-38. https://doi.org/10.1057/palgrave.crr.1550012

Bass, B. M., \& Avolio, B. J. (1994). Improving Organizational Effectiveness Through Transformational Leadership. Thousand Oaks: Sage.

Bauch, P. (2014). Catholic schools in the public interest: Past, present, and future directions. North Carolina: Information Age Publishing.

Bjurström, E. (2012). Minding the contexts of mindfulness in quality management. International Journal of Quality and Reliability Management, 29(6), 699-713. https://doi.org/10.1108/02656711211245674

Bridgmon, K. D., \& Martin, W. E. (2012). Quantitative and statistical research methods: From hypothesis to results. San Francisco: John Wiley and Sons.

Brief, A., \& Weiss, H. (2002). Organizational behavior: affect in the workplace. Annual Review Psychology, 52, 279-307. ttps://doi.org/10.1146/annurev.psych.53.100901.135156

Chaskalson, M. (2011). The mindful workplace developing resilient individuals and resonant organizations with Mbsr. Oxford: John Wiley \& Sons. https://doi.org/10.1002/9781119976974

Collard, P. (2014). The little book of mindfulness. London: Gaia Books.

Dane, E. (2011). Paying attention to mindfulness and its effects on task performance in the workplace. Journal of Management, 37(2), 997-1018. https://doi.org/10.1177/0149206310367948

Fatema, A. (2019). Exploring educational leadership practices of collective mindfulness and organizational conditions (Doctoral dissertation). Retrieved from ProQuest Dissertation \& Theses: Full Text (NR 
13859934).

Fiol, C. M., \& O'Connor, E. (2003). Waking Up! Mindfulness in The Face of Bandwagons. The Academy of Management Review, 28(1), 54-70. https://doi.org/10.2307/30040689

Fraser, A. (2017). Discovering the leader within: An autoethnophenomenographic study of mindfulness in educational leadership (Doctoral dissertation). Retrieved from ProQuest Dissertation \& Theses: Full Text (NR 10690468).

Gay, L. R., Mills, G. E., \& Airasian, P. (2009). Educational Research: Competencies for Analysis and Applications. Pearson: New Jersey.

Gebauer, A. (2012). Mindful organizing as a paradigm to develop managers. Journal of Management Education, 37(2), 203-228. https://doi.org/10.1177/1052562912458573

Geijsel, F. P., Sleegers, P. J. C., Stoel, R. D., \& Krüger, M. L. (2009). The effect of teacher psychological, school organizational and leadership factors on teachers' professional learning in Dutch schools. Elementary School Journal, 109(4), 406-427. https://doi.org/10.1086/593940

Geijsel, F. P., Van den Berg, R., \& Sleegers, P. J. C. (1999). The innovative capacity of schools in primary education: A qualitative study. International Journal of Qualitative Studies in Education, 12(2), 175-191. https://doi.org/10.1080/095183999236240

George, D., \& Mallery, P. (2010). SPSS For windows step by Step: A simple guide and reference, 17.0 update. Boston: Pearson.

Gieseke, A. R. (2014). The relationship between spiritual intelligence, mindfulness, and transformational leadership among public higher education leaders (Doctoral dissertation). Retrieved from ProQuest Dissertation \& Theses: Full Text (NR3617784).

Giluk, T. (2009). Mindfulness, big five personality, and affect: A meta-analysis. Personality and Individual Diferences, 47(8), 805-811. https://doi.org/10.1016/j.paid.2009.06.026

Glomb, T., Duffy, Bono, J., \& Yang, T. (2011). Mindfulness at work. Research in Personnel and Human Resources Management, 30(1), 15-157. https://doi.org/10.1108/S0742-7301(2011)0000030005

Habib, M, Pathik, B., \& Maryam, H. (2014). Research methodology - Contemporary practices: Guidelines for academic researchers. Tyne: Cambridge Scholars Publishing.

Hacker, S., \& Tammy, R. (2003). Transformational leadership: Creating organizations of meaning. ASQ Quality Press.

Hallinger, P. (2003). Leading educational change: reflections on the practice of instructional and transformational leadership. Cambridge Journal of Education, 33(3), 329-351. https://doi.org/10.1080/0305764032000122005

Hanson, A. (2019). The relationship between stress, burnout, and mindfulness among firefighters (Unpublished doctoral thesis). Grand Canyon University.

Horowitz, R. (2012). An exploratory study of the impact of college student leadership programs upon the construct of mindfulness (Doctoral dissertation). Retrieved from ProQuest Dissertation \& Theses: Full Text (NR 3512267).

Hoy, W. K. (2002). Faculty trust: A key to student achievement. Journal of School Public Relations, 23(2), 87-108. https://doi.org/10.3138/jspr.23.2.88

Hoy, W. K. (2003). An analysis of enabling and mindful school structures: Some theoretical, research and practical considerations. Journal of Educational Administration, 41(1), 87-108. https://doi.org/10.1108/09578230310457457

Hoy, W. K., Gage, C. Q., \& Tarter, C. J. (2004). Theoretical and empirical foundations of mindful school structure. In W. K. Hoy, \& C. Miskel (Eds.), Educational organization, policy and reforms: Research and measurement (pp. 305-335). Greenwich: Information Age Publishing.

Hoy, W. K., Gage, C. Q., \& Tarter, C. J. (2006). School mindfulness and faculty trust: Necessary conditions for each other? Educational Administration Quarterly, 42(2), 236-255. https://doi.org/10.1177/0013161x04273844

İnal, C., \& Günay, S. (1993). Olasıllk ve matematiksel istatistik [Probability and mathematical statistics]. Ankara: Hacetepe Üniversitesi Yayınları. 
Jung, D., \& Avolio, B. (2000). Opening the black box: An experimental investigation of the mediating effects of trust and value congruence on transformational and transactional leadership. Journal of Organizational Behavior, 21(8), 949-964. https://doi.org/10.1002/1099-1379(200012)21:8<949::aid-job64>3.0.co;2-f

Kaiser, R., Hogan, R., \& Craig, S. (2009). Leadership and the fate of organizations. American Psychologist, 63(2), 96-110. https://doi.org/10.1037/0003-066X.63.2.96

Kavanagh, M., \& Ashkanasy, N. (2006). The impact of leadership and change management strategy on organizational culture and individual acceptance of change during a merger. British Academy of Management, 17, 81-103. https://doi.org/10.1111/j.1467-8551.2006.00480.x

Kearney, W. S., Kelsey, C., \& Herrington, D. (2013). Mindful leaders in highly effective schools: A mixed-methods application of Hoy's M-scale. Educational Management Administration and Leadership, 41(3), 316-335. https://doi.org/10.1177/1741143212474802

Kent, M. (2015). Mindfulness: A strategy to promote nurse manager leadership styles (Unpublished doctoral thesis). Columbia University.

King, D. (2002). The changing shape of leadership. Educational Leadership, 59(8), 61-63. https://doi.org/10.1002/bl.63

Klockner, K., \& Queensland, B. (2017). Developing organizational resilience: Organisational mindfulness and mindful organizing. Australian Journal of Emergency Management, 32(4), 47-51.

Knox, G. E., Simpson, K. R., \& Garite, T. J. (1999). High reliability perinatal units: An approach to the prevention of patient injury and medical malpractice claims. Journal of Healthcare Risk Management, 19(2), 24-31. https://doi.org/10.1002/jhrm.5600190205

Langer, E. J. (1992). Matters of mind: Mindfulness/Mindlessness in perspective. Consciousness and Cognition, 1, 289-305. https://doi.org/10.1016/1053-8100(92)90066-j

Langer, E., \& Ngnoumen, C. (2017). Mindfulness. In D. S. Dunn (Ed.), Positive psychology (pp. 17-65). London: Taylor Francis. https://doi.org/10.4324/9781315106304-7

Langer, E., J., \& Moldoveonu, M. (2000). The construct of mindfulness. The Journal of Social Issues, 56(1), 1-9. https://doi.org/10.1007/978-3-319-30782-4_2

Leithwood, K. (1992). The move toward transformational leadership. Educational Leadership, 49, 8-12.

Long, E., \& Christian, E. (2015). Mindfulness buffers retaliatory responses to injustice: A regulatory approach. Journal of Applied Psychology, 100(5),1409-1422. https://doi.org/10.1037/apl0000019

Madsen, P., Desai, V., Roberts, K., \& Wong, D. (2016). Mitigating hazards through continuing design: The birth and evolution of a pediatric intensive care unit. Organization Science, 17(2), 239-248. https://doi.org/10.1287/orsc. 1060.0185

Marks, H. M., \& Printy, S. M. (2003). Principal leadership and school performance: An integration of transformational and instructional leadership. Educational Administration Quarterly, 39(3), 370-397. https://doi.org/10.1177/0013161x03253412

Marshall, E. (2011). Transformational leadership in nursing: From expert clinician to influential leader. New York: Springer Publishing Company.

May, J. D. (2016). The effects of individual and school mindfulness on the academic optimism in schools in North Alabama (Doctoral dissertation). Retrieved from ProQuest Dissertation \& Theses: Full Text (NR10162705).

McMillan, J. H., \& Schumacher, S. (2010). Research in education: Evidence-based inquiry. Pearson: Boston.

Milner, E., \& Joyce, P. (2005). Lessons in leadership: Meeting the challenges of public service management. New York: Routledge.

Mu, E., \& Butler, B, S. (2012). The assessment of organizational mindfulness processes for the effective assimilation of it innovations. Journal of Decision Systems, 18(1), 27-51. https://doi.org/10.3166/jds.18.27-51

Ndubisi, N. (2012). Mindfulness, quality and reliability in small and large firms. International Journal of Quality and Reliability Management, 29(6), 600-606. https://doi.org/10.1108/02656711211245683

Northouse, P. G. (20149. Liderlik kuram ve uygulamalarl [Leadership theory and practice]. Istanbul: Sürat. 
Ott, S., \& Shafritz, J. (1994). Toward a definition of organizational incompetence: A neglected variable in organization theory. Public Administration Review, 54(3), 370-377. https://doi.org/10.2307/977385

Özen, Y. \& Gül, A. (2007). Sosyal ve eğitim bilimleri araştırmalarında evren ve örneklem sorunu [Population-sampling issue on social and educational research studies]. KKEFDI/OKKEF, 2(1).

Peterson, K., J. (2015). Mindful instructional leadership practices of elementary principals in Washington State (Doctoral dissertation). Retrieved from ProQuest Dissertation \& Theses: Full Text (NR3717439).

Piccolo, R. F., \& Colquitt, J. A. (2006). Transformational leadership and behaviors: The mediating role of core job characteristics. Academy of Management Journal, 49(2), 327-340. https://doi.org/10.1108/09534810410530584

Pillai, R., \& Williams, E. (2003). Transformational leadership, self-efficacy, group cohesiveness, commitment, and performance. Journal of Organizational Change Management, 17(2), 144-159. https://doi.org/10.1108/09534810410530584

Reb, J., Narayanan, J., \& Chaturvedi, S. (2004). Leading mindfully: Two studies of the influence of supervisor trait mindfulness on employee wellbeing and performance. Mindfulness, 5(1), 36-45. https://doi.org/10.1007/s12671-012-0144-z

Rerup, C., \& Levinthal, D. (2013). Situating the concept of organizational mindfulness: The multiple dimensions of organizational learning. In G. Becke (Ed.), Mindful change in times of permanent reorganization: Organizational, institutional and sustainability perspectives (pp. 33-49). Springer. https://doi.org/10.1007/978-3-642-38694-7_3

Roche, M., Haar, J., \& Fred, L. (2014). The role of mindfulness and psychological capital on the well-being of leaders. Journal of Occupational Health Psychology, 19(4), 476-489. https://doi.org/10.1037/e528472014-021

Rodriquez, J. A. S. (2015). Mindful introductional leadership: The connection between principal mindfulness and school practices (Doctoral dissertation). Retrieved from ProQuest Dissertation \& Theses: Full Text (NR 3717473).

Satia, S., Kumar, A., \& Liow, M. (2014). Visionary leadership in health: Delivering superior value. California: SAGE Publications.

Scarbrough, C. S. (2005). Aspects of School Mindfulness and Dimensions of Faculty Trust: Social Processes in Elementary School (Doctoral dissertation). Retrieved from ProQuest Dissertation \& Theses: Full Text (NR 3195504).

Schwahn, C. J., \& Spady, W. G. (1998). Total leaders: Applying the best future-focused change strategies to education. Lanham, MD: Scarecrow Press.

Shapiro, S., Wang, M. \& Peltason, E. (2015). What is mindfulness, and why organizations care about it? In J. Reb, \& P. W. B. Atkins (Eds.), Mindfulness in organizations: Foundations, research, and applications (pp. 17-42). Cambridge: Cambridge University Press. https://doi.org/10.1017/CBO9781107587793.004

Slevitch, L. (2011). Qualitative and quantitative methodologies compared: Ontological and epistemological perspectives. Journal of Quality Assurance in Hospitality and Tourism, 12, 73-78. https://doi.org/10.1080/1528008X.2011.541810

Smith, B. (2016). The role of leadership style in creating a great school. SELU Research Review Journal, 1(1), 65-78.

Smith, K., \& Larimer, C. (2004). A mixed relationship: Bureaucracy and school performance. Public Administration Review, 64(6), 728-736. https://doi.org/10.1111/j.1540-6210.2004.00419.x

Smith, P., \& Scarbrough, C. S. (2011). Mindful schools as high-reliability organizations: The effect of trust on organizational mindfulness. In M. F. DiPaola, \& M. P. Forsyth (Eds), Leading research in educational administration, A festschrift for Wayne K. Hoy (pp. 17-45). Charlotte: Information Age Publishing.

Spanjian, J. (2019). Self-perceived impact of mindfulness on engineers ( $\mathrm{PhD}$ dissertation, The Graziadio Business School, USA).

Stoner-Zemel, M. J. (1988). Visionary leadership, management, and high performing work units: An analysis of workers' perceptions (Doctoral dissertation). Retrieved from ProQuest Dissertation \& Theses: Full Text (NR8823744). 
Sutherland, I., \& Gosling, J. (2010). Cultural leadership: Mobilizing culture from affordances to dwelling. The Journal of Arts Management Law and Society, 40, 6-26. https://doi.org/10.1080/10632921003603984

Sümbüloğlu, K. (1993). Biyoistatistik [Biostatistics]. Ankara: Özdemir Yayıncılık.

Tabachnick G., \& Fidell L. S. (2013). Using multivariate statistics. Boston: Pearson.

Tabancal, E., \& Öngel, G. (2020). Examining the relationship between school mindfulness and organizational trust. International Education Studies, 13(6), 14-25. https://doi.org/10.5539/ies.v13n6p14

Tahaoğlu, F., \& Gedikoğlu, T. (2009). Leadership Roles of Primary School Principals. Educational Administration: Theory and Practice, 15(58), 274-298.

Tarela, O., \& Gbaraka, K. (2018). Leader mindfulness and employee work attitudes in public agencies in port harcourt. International Journal of Business and Management Review, 6(3), 101-114.

Tekel, E., \& Karadağ, E. (2019). School bullying, school mindfulness and school academic performance: A structural equation modeling study. Journal of Psychologists and Counsellors in Schools, 30(2), 129-135. https://doi.org/10.1017/jgc.2019.10

Valentine, S. G., \& S. Varca, P. (2009). Role conflict, mindfulness, and organizational ethics in an education-based healthcare institution. Journal of Business Ethics, 94(3), 455-469. https://doi.org/10.1007/s10551-009-0276-9

Vogus, T., \& Sutchlife, K. (2012). Organizational mindfulness and mindful organizing: A reconciliation and path forward. Academy of Management Learning and Education, 11(4), 722-735. https://doi.org/10.5465/amle.2011.0002c

Walsh, M., \& Arnold, K. A. (2017). Mindful leadership and employee well-being the mediating role of leader behaviors. In K. Kelloway, K. Nielsen, \& J. K. Dimoff (Eds.), Leading to occupational health and safety: How leadership behaviors impact organizational safety and well-being (pp. 235-254). Oxford: John Wiley $\&$ Sons.

Weick, K., \& Putnam, T. (2006). Organizing for mindfulness. Journal of Management Inquiry, 15(3), 1-13. https://doi.org/10.1002/9781118294895.ch22

Weick, K., \& Sutcliffe, K. (2001). Managing the unexpected: Assuring high performance in an age of complexity. San Francisco: Jossey-Bass.

Weick, K., \& Sutcliffe, K. (2006). Mindfulness and the quality of organizational attention. Organization Science, 17(4), 417-526. https://doi.org/10.1287/orsc.1060.0196

Wolf, M., Vykoukal, J., \& Beck, R. (2009). Innovating mindfully with service-oriented grids-The role of organizational mindfulness in turbulent environments. Association for Information Systems AIS Electronic Library, 6, 1-15.

Yammarino, F. (1994). Indirect leadership: Transformational leadership at a distance. In B. M. Bass, B. J. Avolio (Eds.), Improving organizational effectiveness through transformational leadership (pp. 26-46). London: Sage.

Youngs, C. E. (2018). Organizational mindfulness and mindful organizing in effective high schools: Mixed-methods study of department leaders' perceptions (Doctoral dissertation). Retrieved from ProQuest Dissertation \& Theses: Full Text (NR10936519).

Yu, L., \& Zellmer-Bruhn, M. (2017). Introducing team mindfulness and considering its safeguard role against conflict transformation and social undermining. Academy of Management Journal, 61(1). https://doi.org/10.5465/amj.2016.0094

Zafar, A., Nisar, Q, Shoukat, M., \& Ikram, M. (2017). Green transformational leadership and green performance: The mediating role of green mindfulness and green self-efficacy. International Journal of Management Excellence, 9(2), 1059-1065. https://doi.org/10.17722/ijme.v9i2.346

\section{Copyrights}

Copyright for this article is retained by the author(s), with first publication rights granted to the journal.

This is an open-access article distributed under the terms and conditions of the Creative Commons Attribution license (http://creativecommons.org/licenses/by/4.0/). 